\title{
Errata
}

\section{SEX PHEROMONE OF EGYPTIAN COTTON \\ LEAFWORM (Spodoptera littoralis). ITS CHEMICAL TRANSFORMATION UNDER FIELD CONDITIONS}

\author{
A. SHANI and J.T. KLUG
}

In Ref. 1, the following errors appeared:

Page 876, 6 lines up. Change $N, N$-diethyl-m-toluamide to $N$-octyl- $N^{\prime}$ phenyl-p-phenylenediamine.

Page 877, 11 lines down. Change UOP to DEET.

Page 878, 3 lines down. Change (UOP or BHT) to (DEET or BHT).

Page 879, 5 lines up. Change UOP to DEET.

Page 880,3 rd entry and 6th entry in Table 1 . Change Prodlure and UOP to Prodlure and DEET.

\section{REFERENCE}

Shani, A., and Krug, J.T. 1980. J. Chem. Ecol. 6:875-881.

\section{TRAPPING THE WESTERN PINE BEETLE AT AND NEAR A SOURCE OF SYNTHETIC ATTRACTIVE PHEROMONE: EFFECTS OF TRAP SIZE AND POSITION}

\author{
P.E. TILDEN, W.D. BEDARD, D.L. WOOD, K.Q. LINDAHL, \\ and P.A. RAUCH
}

In Ref. 1, the following error appeared:

The first sentence of the second paragraph below Table 4 on p. 528 should read, "When the surrounding traps were $0.19 \mathrm{~m}^{2}$, the proportion of males 
caught at the source of attractant was significantly different from the proportions caught $1.5 \mathrm{~m}$ away, $1.5 \mathrm{~m}$ high and $4.5 \mathrm{~m}$ away, $3.0 \mathrm{~m}$ high (Table 2). The proportion of males caught $1.5 \mathrm{~m}$ away, $1.5 \mathrm{~m}$ high was significantly different from the proportion caught $1.5 \mathrm{~m}$ away, $3.0 \mathrm{~m}$ high." We thank J.A. Byers for bringing this error to our attention.

\section{REFERENCE}

Tilden, P.E., Bedard, W.D., Wood, D.L., Lindahl, K.Q. and Rauch, P.A. 1979. J. Chem. Ecol. 5:519-531. 